\title{
Supporting, microporous, elastomeric, degradable prostheses to improve the arterialization of autologous vein grafts
}

\author{
W.L.J. Hinrichs, H.-P. Zweep*, S. Satoh*, J. Feijen and Ch.R.H. \\ Wildevuur* \\ Department of Chemical Technology, University of Twente, PO Box 217, 7500 AE Enschede. The Netherlands \\ ${ }^{\star}$ Department of Experimental Cardiopulmonary Surgery, Research Division, University Hospital of Groningen, PO \\ Box 30.001, 9700 RB Groningen. The Netherlands
}

\begin{abstract}
Arterial reconstructions with vein grafts fail more frequently than with arterial grafts. One of the causes of graft failure is damage due to overstretching of the graft wall. Overstretching is caused because the vein graft, which has a poorly developed medium, cannot withstand the arterial blood pressures. The aim of this study is to evaluate whether damage due to overstretching can be prevented and a gradual adaptation of the vein graft to the arterial blood pressures can be induced by applying a microporous, elastomeric, degradable prosthesis around the vein graft. Therefore, autologous vein grafts (length $1.0 \mathrm{~cm}$ ) with and without supporting prostheses (composite vein grafts and control vein grafts, respectively) were interposed into both carotid arteries of rabbits. Microporous, elastomeric, biofragmentable polyurethane-based prostheses and microporous, elastomeric, biodegradable prostheses made of poly-i-caprolactone or a copolymer of i-caprolactone and 3,6dimethyl-1,4-morpholine-2,5-dione with a monomer ratio of 95.5:4.5 were prepared. The grafts were evaluated up to 6 wk after implantation. The control vein grafts showed severe destructive changes such as de-endothelialization, disruption of the media with oedema, degradation of the elastic laminae and infiltration of polymorphonuclear leucocytes into the vein graft wall, leading eventually to a fibrotic wall. In contrast, the composite vein grafts showed a preservation of the smooth muscle cell layers and the elastic laminae with only few polymorphonuclear leucocytes infiltrated into the vein graft wall. Moreover, the wall of the vein graft gradually increased in thickness by the formation of regular circularly oriented cellular layers beneath the original longitudinally oriented smooth muscle cell layers, indicating a gradual adaptation of the vein graft to the arterial conditions. It appeared that the arterialization rate depended on the degradation rate of the supporting prostheses. Microporous prostheses made of a copolymer of :-caprolactone and 3,6-dimethyl-1,4-morpholine-2,5-dione with a monomer ratio higher than 95.5:4.5 are recommended to support the vein grafts.
\end{abstract}

Keywords: Vein grafting, supporting prostheses, degradation

Received 16 February 1993; accepted 22 June 1993

Arterial autografts are the ideal material for the reconstruction of malfunctioning small diameter arteries $^{1}$. After implantation, the graft remains viable and possesses properties like those of a normal artery, such as compliance, flexibility and antithrombogenicity. Its applicability, however, is limited because grafts of the required length and diameter are not always sufficiently available. Moreover, harvesting of these grafts may occasionally lead to tissue necrosis at the donor sites. These limitations of arterial autografts are not or to a lesser extent encountered with the application of venous autografts which are therefore

Correspondence to Professor Dr I. Feijen. still frequently used as grafts for the reconstruction of malfunctioning small diameter arteries ${ }^{2.3}$. 'lhe drawback of this type of graft is its relatively poor graft performance. For example, applied for coronary bypass procedures, the cumulative patency rate in $5 \mathrm{yr}$ for arterial autografts is $93 \%$ and for vein grafts $45 \%{ }^{4}$.

Several investigators have observed that after implantation the vein grafts are damaged, showing deendothelialization, disruption of the medial layers and the development of an inflammatory reaction". Later changes include artherosclerosis, dilation, aneurysm formation and subintimal thickening, which may ultinately lead to graft failure?:3.5-?. It has been proposed that damage to the vein graft is caused by surgical manipulations during transplantation ${ }^{10-16 .}$. 
Therefore, improved handling procedures were developed which indeed resulted in a better graft performance ${ }^{11,12,14,15,17}$. However, other factors which are inherent to the transplantation procedure leading to damage of the vein graft are ischaemia due to the interruption of the vasa vasorum and overstretching of the vein graft wall due to the arterial blood pressure $^{13,18-20}$. Overstretching is caused because the vein graft has a poorly developed medium with few smooth muscle cell layers which is not adapted to the relatively high arterial pressures. Overstretching may lead to a loss of the integrity of the graft wall and ultimately to graft failure. Therefore, it is expected that if overstretching is prevented, the graft performance will be improved. This was confirmed by Barra et al. ${ }^{21}$ and Karayannacos et $a l^{22}$, who have shown that a constrictive Dacron mesh applied around the vein graft reduces the degree of deterioration of the vein wall. The long-term fate of these composite vein grafts, however, might be less successful. These prostheses are non-compliant, which might induce intimal hyperplasia formation at the anastomotic sides ${ }^{23}$. Furthermore, the prostheses are non-resorbable, which might cause perigraft fibrosis ${ }^{24}$ and ultimately constriction of the grafts.

The aim of this study was to evaluate whether damage due to overstretching can be prevented and a gradual adaptation of the vein graft to the arterial blood pressures can be induced by applying a microporous, elastomeric, degradable prosthesis around the vein graft. Therefore, autologous vein grafts (length $1.0 \mathrm{~cm}$ ) with and without supporting prostheses (composite vein graft and control vein graft, respectively) were interposed into both carotid arteries of rabbits and evaluated up to $6 \mathrm{wk}$ after implantation. To study the effects of degradation of the prostheses on the arterialization process, different compositions of prostheses with different degradation rates were tested. A discussion will be given on the suitability of several types of polymer systems for this application.

\section{MATERIALS AND METHODS}

\section{Materials}

Polyetherurethane Estane ${ }^{\text {R }}$ 5714fl (PEU; Goodrich, Leidschendam, The Netherlands) was purified by precipitation of a $10 \mathrm{wt} \%$ solution in $N, N$-dimethylformamide (DMF) into water. Poly- $\varepsilon$-caprolactone (PCl; Interox Chemical Ltd, Warrington, UK) and poly(Llactide) (PLLA; TNO, Delft, The Netherlands) were purified by precipitation of $10 \mathrm{wt} \%$ solutions in chloroform $\left(\mathrm{CHCl}_{3}\right)$ into methanol. $\Lambda$ copolymer of $\varepsilon$-caprolactone and 3,6-dimethyl-1,4-morpholine-2,5-dione (monomer ratin 95.5:4.5; Cop 4.5) was synthesized as described by in't Veld et al. ${ }^{25}$. The intrinsic viscosities of solutions of PLLA in $\mathrm{CHCl}_{3}$ and of PCl and Cop 4.5 in tetrahydrofuran (THF), as determined with an Ubbelohde viscometer at $25^{\circ} \mathrm{C}$, were $2.60,0.63$ and $0.82 \mathrm{dl} / \mathrm{g}$, respectively.

Fractions of sodium citrate (Janssen, Beerse, Belgium) differing in particle size were obtained as follows. A saturated solution of sodium citrate in a $1: 2(\mathrm{v} / \mathrm{v})$ mixture of methanol and water was cooled from 70 to $4^{\circ} \mathrm{C}$ to induce crystallization of sodium citrate. Subsequently, the formed crystals were filtered, rinsed with ethanol and then dried. Sodium citrate thus obtained was fractionated with Tamson test sieves (Zoetermeer, The Netherlands) with mesh sizes of 38 , 63 and $106 \mu \mathrm{m}$ to obtain crystals with the following sizes: smaller than $38 \mu \mathrm{m}, 38-63 \mu \mathrm{m}$ and $63-106 \mu \mathrm{m}$, respectively.

Methanol, ethanol, DMF, THF, dimethylsulphoxide (DMSO) and $\mathrm{CHCl}_{3}$ (all Merck, Darmstadt, Germany) were of synthesis or analytical grade and were used without further purification.

\section{Fabrication and characterization of the prostheses}

Prostheses composed of PEU-PLLA (90:10 wt\%) and PEU-PCl $(90: 10 w t \%)$ were prepared by means of a repeated immersion precipitation/salt casting technique ${ }^{26.27}$. A glass rod (diameter $2.5 \mathrm{~mm}$ ) was dipped into a suspension of a polymer solution and sodium citrate particles at ambient temperaturc. Subsequently, the glass rod on which a layer of the suspension was deposited was placed for $5 \mathrm{~s}$ into ethanol-water (90:10 $w t \%)$ and thereafter for $10 \mathrm{~min}$ into ethanol-water (50:50 wt\%), also at ambient temperature to induce polymer precipitation. Thereafter the precipitated polymer was exposed to air until nearly dry and the next layer was deposited on top of the first one by means of the same procedure. This procedure was continued until five layers were deposited. Then the prostheses were thoroughly rinsed in water and ethanol to dissolve the salt particles and to extract the solvent residues, and subsequently stored in ethanol. The composition of the suspension used for the preparation of the first four layers was PEU-PLLA$\mathrm{DMF}-\mathrm{THF}-\mathrm{CHCl}_{3}$-sodium citrate (particle size $<38 \mu \mathrm{m})(4.5: 0.5: 44.0: 12.0: 28.4: 10.6 \mathrm{wt} \%)$ or PEU-PClDMF-THF-sodium citrate (particle size $<38 \mu \mathrm{m}$ ) (5.4:0.6:69.0:12.1:12.9 $\mathrm{wt}^{\%}$ ) and for the last layer PEU-PLLA-DMF-THF-CHCl ${ }_{3}$-sodium citrate (particle size $68-106 \mu \mathrm{m}) \quad(3.4: 0.3: 38.0: 4.8: 23.0: 30.5 w \mathrm{w} \%)$ or PEU-PCl-DMF-THF-sodium citrate (particle size 68$106 \mu \mathrm{m})(4.5: 0.5: 49.1: 8.7: 37.2 \mathrm{wt} \%)$.

Prostheses composed of $\mathrm{PCl}$ were prepared by means of a two-step thermally induced phase separation/salt casting technique ${ }^{27}$. These prostheses were also prepared by depositing a number of layers onto a glass rod (diameter $2.5 \mathrm{~mm}$ ) by means of dip coating. In this case, polymer precipitation was induced by cooling a suspension of a polymer solution and sodium citrate particles. After the glass rod was dipped into the suspension at $60^{\circ} \mathrm{C}$, the glass rod containing a layer of the suspension was cooled to ambient temperature for $15 \mathrm{~min}$. Subsequently, the prostheses were placed into water-ethanol ( $25: 75 \mathrm{wt} \%)$ for $15 \mathrm{~min}$, also at ambient temperature, to partially extract the solvent. The prostheses were then exposed to air until nearly dry and the second layer was deposited by means of the same procedure. After two layers had been deposited, the prostheses were treated like the PEU-based prostheses. The composition of the suspension used for the preparation of the first layer was $\mathrm{PCl}-\mathrm{DMSO}$-sodium citrate (particle size $<38 \mu \mathrm{m})(10: 57.3: 32.7 \mathrm{wt} \%)$ and 
for the second layer PCl-DMSO-sodium citrate (particle size 38-63 $\mu \mathrm{m})(6.7: 53.3: 40.0 \mathrm{wt} \%$ ).

Prostheses composed of Cop 4.5 were prepared by means of a repeated evaporation precipitation/salt casting technique ${ }^{26}$. These prostheses were prepared by means of a similar procedure as used for the preparation of the PEU-based prostheses except that the method of polymer precipitation was changed. Instead of innersing a suspension of a polymer solution and sodium citrate particles into a nonsolvent, polymer precipitation was induced by allowing the solvent to evaporate by air exposure for 5 min at ambient temperature after the deposition of each layer. In total, seven layers were deposited onto the glass rod (diameter $2.5 \mathrm{~mm}$ ). The composition of the suspension used for the preparation of the first six layers was Cop 4.5- $\mathrm{CHCl}_{3}$-sodium citrate (particle size $<38 \mu \mathrm{m})(4.7: 77.9: 17.4 \mathrm{wt} \%)$ and for the last layer Cop 4.5- $\mathrm{CHCl}_{3}$-sodium citrate (particle size 68-106 $\mu \mathrm{m}$ ) $(2.2: 80.6: 17.2 \mathrm{wt} \%)$.

The porous structures of the prostheses were cvaluatcd by means of scanning clcctron microscopy (SEM). Therefore, the prostheses were coated with a layer of gold with a Balzer sputter unit and examined with a Jeol JSM 35 scanning electron microscope operating at $15 \mathrm{kV}$.

The mechanical properties of the prostheses were evaluated by means of stress-strain measurements. The prostheses were wetted with distilled water and subsequently fixed between the clamps of an Instron tensile tester (Floor model TT-CM). The prostheses $(n=3)$, with a length of $1 \mathrm{~cm}$, were drawn in the longitudinal direction with a speed of $0.5 \mathrm{~cm} / \mathrm{min}$ at $25^{\circ} \mathrm{C}$ until breakage.

\section{Implantation}

Both left and right carotid arteries of male Chinchilla rabbits weighing $3.0-3.5 \mathrm{~kg}$ were used to evaluate composite vein grafts consisting of autologous veins surrounded by prostheses. The site of implantation (left or right carotid artery) was randomized. Microporous prostheses composed of PEU-PLLA (90:10 wt \%), PEU-PCl (90:10 wt\%), Cop 4.5 and $\mathrm{PCl}$ were used. The prostheses were sterilized by ethylene oxide (PEUbased prostheses) or by ethanol (Cop 4.5 and PCl prostheses). After the rabbit was anaesthesized by intravenous injection of sodium pentobarbitone (Nembutol, $30 \mathrm{mg} / \mathrm{kg}$ ) and intubated with $1 \%$ halothane (Fluothane), the carotid arteries and the jugular veins were carefully exposed by making a ventral midline incision in the neck under sterile conditions. One centimetre segments of the jugular veins were harvested and interposed into the carotid arteries with end to end anastomoses. The vein grafts were implanted by means of microsurgical techniques, as described before ${ }^{28}$. The vein grafts with supporting prostheses were implanted as shown schematically in Figure 1. The prostheses had a length of $1.5 \mathrm{~cm}$ and overlapped both anastomoses. Both types of graft were anastomosed to the carotid arteries with interrupted sutures (Ethilon 9-0, BV-4 needle, Ethicon). Vein grafts matching the diameter of the carotid artery $(2.5 \mathrm{~mm})$ and oversized vein grafts $(3.5 \mathrm{~mm})$ were uscd for the

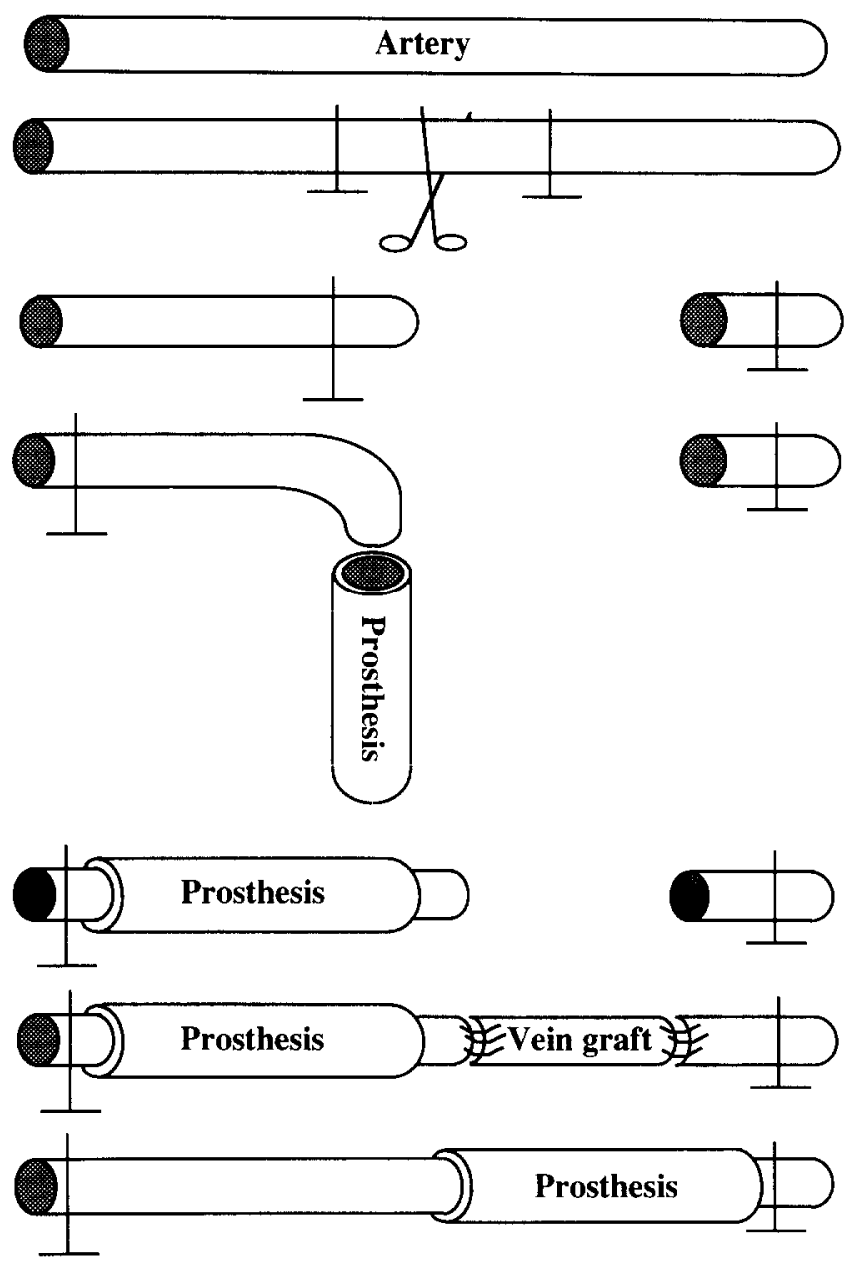

Figure 1 Schematic drawing of the implantation of the composite vein graft.

Table 1 In vivo experiments

\begin{tabular}{llcl}
\hline & \multicolumn{3}{c}{ Implantation time } \\
\cline { 2 - 4 } & $1 \mathrm{wk}$ & $3 w \mathrm{wk}$ & $6 \mathrm{wk}$ \\
\hline Control & $n \ldots 6$ & $n=6$ & $n=8$ \\
PEU-PCI $(9: 1)$ & $n=6$ & $n=6$ & $n=7$ \\
PEU-PLLA $(9: 1)$ & $n=6$ & $n=6$ & $n=8$ \\
PCI & $n=2$ & $n=2$ & $n=1$ \\
Cop 4.5 & $n=6$ & $n=6$ & $n=8$ \\
\hline
\end{tabular}

control and composite grafts, respectively. The grafts were harvested at different time intervals (see Table 1) and prepared for SEM and light microscopy (LM) by means of standard procedures ${ }^{29.30}$. The wall thickness and the inner diameter of the explanted vein grafts and the carotid artery were determined as described before ${ }^{30}$. The data were mutually compared by means of the Mann-Whitney test. The data were considered to be significantly different when $P<0.05$.

\section{RESULTS}

\section{Characteristics of the prostheses}

For the characteristics of the prostheses, see Table 2. Two different pore structures were obtained (see Figure 2): sponge-like structures with highly intercon- 
Table 2 Characteristics of the prostheses

\begin{tabular}{|c|c|c|c|c|c|c|c|}
\hline $\begin{array}{l}\text { Composition } \\
\text { prostheses }\end{array}$ & $\begin{array}{l}\text { Wall } \\
\text { thickness } \\
(\mathrm{mm})\end{array}$ & $\begin{array}{l}\text { Internal } \\
\text { diameter } \\
(\mathrm{mm})\end{array}$ & $\begin{array}{l}\text { Pore size } \\
(\mu \mathrm{m})\end{array}$ & $\begin{array}{l}\text { Wall density } \\
\left(\mathrm{mg} / \mathrm{mm}^{3}\right)\end{array}$ & $\begin{array}{l}\text { Weight/ } \\
\text { length } \\
(\mathrm{mg} / \mathrm{mm})\end{array}$ & $\begin{array}{l}\text { Strain at } \\
\text { breakage } \pm \\
\text { s.d. }(\%)\end{array}$ & $\begin{array}{l}\text { Force at } \\
\text { breakage } \pm \\
\text { s.d. (N) }\end{array}$ \\
\hline PEU-PCI $(9: 1)$ & 0.40 & 2.5 & $30-100$ & 0.26 & 1.13 & $>400$ & $>2.0$ \\
\hline PEU-PLLA (9:1) & 0.35 & 2.5 & $30-100$ & 0.36 & 0.95 & $>400$ & $>1.5$ \\
\hline $\mathrm{PCl}$ & 0.90 & 2.5 & $75-150$ & 0.14 & 1.30 & $80 \pm 9$ & $2.9 \pm 0.3$ \\
\hline Cop 4.5 & 0.70 & 2.5 & $30-100$ & 0.26 & 1.83 & $100 \pm 12$ & $3.7 \pm 0.4$ \\
\hline
\end{tabular}

"Pore size inner side - outer side.

nected pores (PEU-based and PCl prostheses) and leafy structures with poorly interconnected pores (Cop 4.5 prostheses). With the preparation of the PEU-based and $\mathrm{PCl}$ prostheses, pores were formed by two different mechanisms. Pores in these prostheses were formed by the entrapment of sodium citrate particles in the polymer matrix during precipitation and the subsequent extraction of the sodium citrate particles and by demixing processes occurring during precipitation $^{27}$. Both pore-forming mechanisms resulted in the formation of sponge-like structures with highly interconnected pores. With the preparation of the Cop 4.5 prostheses, pores were only formed by the entrapment of sodium citrate particles in the polymer matrix during precipitation and the subsequent extraction of the sodium citrate particles ${ }^{27}$. Therefore, these prostheses had a different pore morphology. The prostheses showed a leafy structure with a relatively poor interconnectivity of the pores.

All four types of prosthesis showed elastomeric behaviour at $25^{\circ} \mathrm{C}$ (see Figure 3). However, the elastomeric properties of the $\mathrm{PCl}$ and Cop 4.5 prostheses as expressed in the values for the strain at breakage were not as good as those of the PEU-based prostheses. Furthermore, the $\mathrm{PCl}$ and Cop 4.5 prostheses had higher initial moduli than the PEU-based prostheses. These differences can be ascribed to differences in specific characteristics of the materials from which the prostheses were made, as well as to differences in weight per length of the prostheses.

\section{In vivo experiments}

\section{Control grafts}

One week implants: the inner surfaces of the control vein grafts were denuded from endothelium for $50 \%$. The graft wall had an edematous appearance and was infiltrated by many polymorphonuclear leucocytes. Furthermore, the smooth muscle layers were completely disrupted and showed only fragments of the elastic laminae (see Figure 4a).

Three week implants: the endothelium was fully recovered and the edema had disappeared. Irregular proliferated cells, most likely mature fibroblasts ${ }^{29}$, had partially replaced the areas of inflammation, while the elastic laminae could no longer be observed.

Six week implants: irregular proliferated mature fibroblasts had completely replaced the areas of inflammation (see Figure $4 b$ ).

\section{Composite grafts}

One week implants: the inner surface of the composite vein grafts were denuded from endothelium for $20 \%$
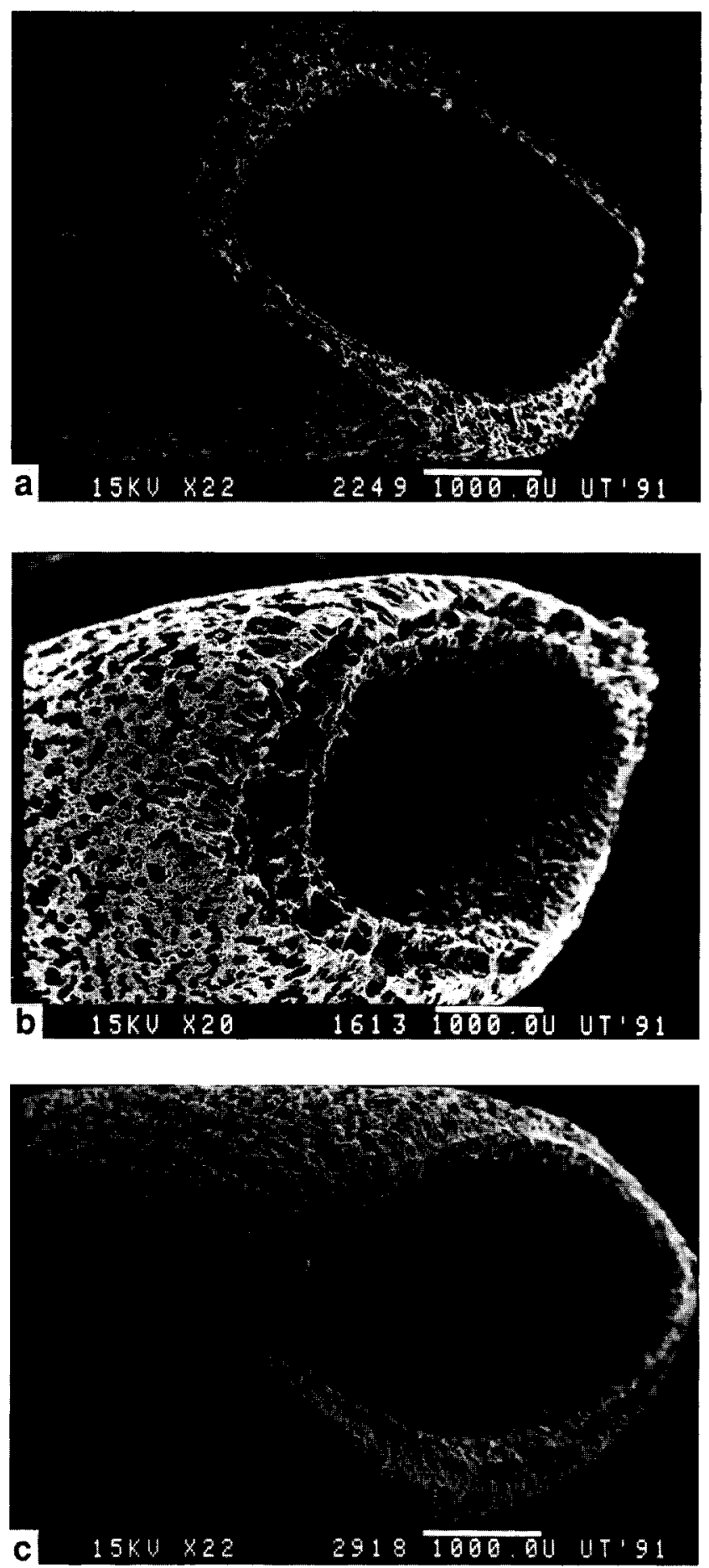

Figure 2 SEM micrographs of the prostheses. a, PEUPLLA prosthesis. b, $\mathrm{PCl}$ prosthesis. c, Cop 4.5 prosthesis (the PEU-PCl prosthesis had a similar appearance to the PEU-PLLA prosthesis). 


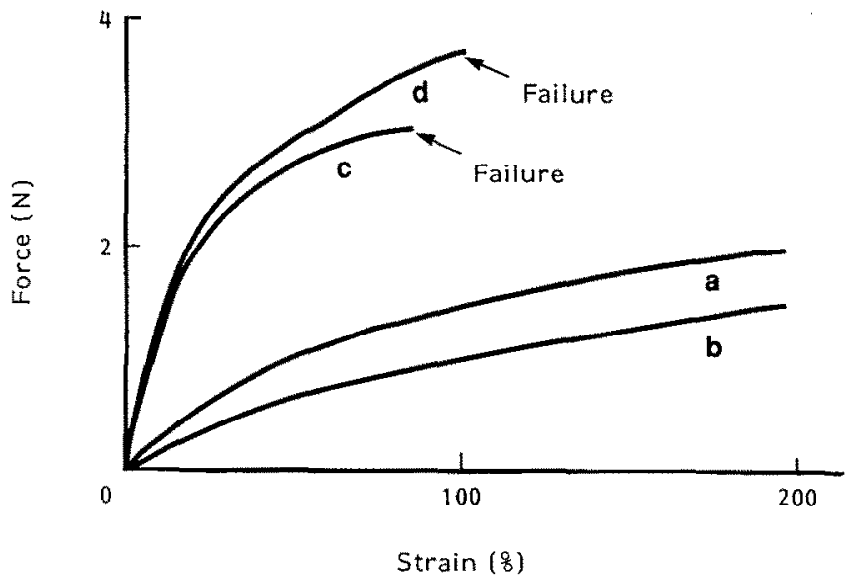

Figure 3 Examples of force-strain curves of: $\mathbf{a}$, the PEU$\mathrm{PCl}$ prothesis; $\mathbf{b}$, the PEU-PLLA prosthesis; $c$, the $\mathrm{PCl}$ prosthesis; and $\mathbf{d}$, the Cop 4.5 prosthesis. only. The graft wall showed no edema and only few polymorphonuclear leucocytes had infiltrated. The smooth muscle cell layers, including the elastic laminae, were hardly affected. No major histological differences were observed between the four types of composite vein grafts (see Figure $4 \mathrm{C}$ ). The inner diameter of all vein grafts was equal to that of the adjacent artery (see Table 3). The wall thickness of the vein grafts was the same in all cases, but smaller than that of the adjacent artery (see Table 4). None of the prostheses showed signs of fragmentation. Furthermore, the prostheses showed limited perigraft tissue ingrowth.

Three week implants: the endothelium was fully recovered and infiltrated polymorphonuclear leucocytes could no longer be observed. The vein grafts supported by the Cop 4.5 prostheses were dilated as compared to the adjacent artery. In all other
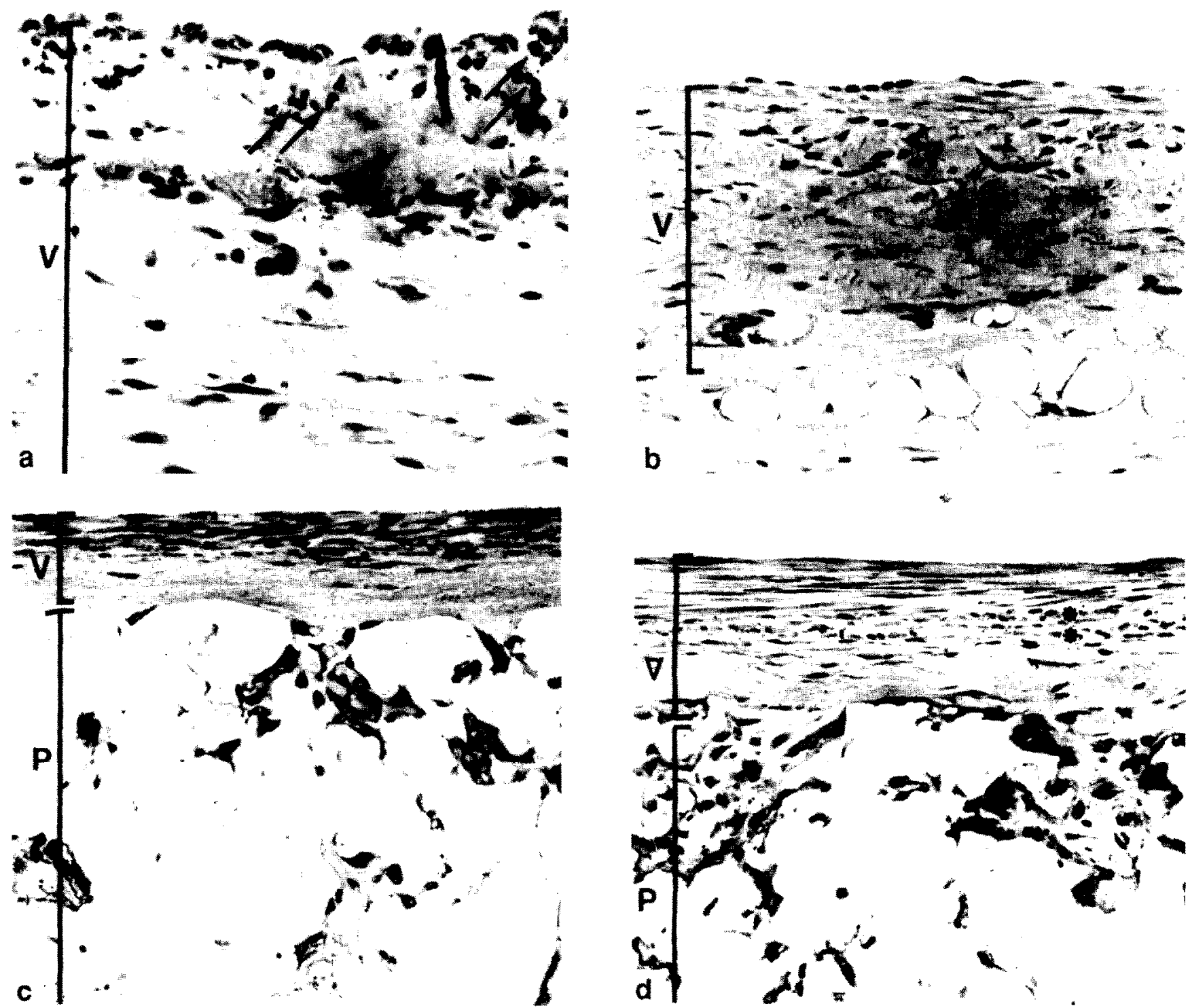

Figure 4 Light micrographs of the vein grafts. a, Control vein graft 1 wk after implantation showing disrupted smooth muscle cell layers and infiltrated polymorphonuclear leucocytes (see arrows). b, Control vein graft 6 wk after implantation showing irregular proliferation of mature fibroblasts. c, Composite vein graft (PEU-PCl prosthesis) 1 wk after implantation showing preserved smooth muscle cell layers and hardly any infiltrated polymorphonuclear leucocytes. d, Composite vein graft (PEU-PCl prosthesis) 6 wk after implantation showing an increased thickness of the vein graft wall and several layers of circularly oriented immature fibroblasts (asterisks) underneath the original longitudinally oriented smooth muscle cell layers. $V$, vein wall; $P$, prosthesis. Magnification $\times 250$. 
Table 3 Inner diameter of the implants

\begin{tabular}{llll}
\hline Graft & \multicolumn{3}{c}{ Inner diameter $(\mathrm{mm})$} \\
\cline { 2 - 4 } & $\begin{array}{l}\text { 1 wk } \\
\text { implants }\end{array}$ & $\begin{array}{l}\text { 3 wk } \\
\text { implants }\end{array}$ & $\begin{array}{l}\text { 6 wk } \\
\text { implants }\end{array}$ \\
\hline PEU-PCl & $1.04 \pm 0.13$ & $1.06 \pm 0.13$ & $1.11 \pm 0.13$ \\
PEU-PLLA & $1.00 \pm 0.11$ & $1.08 \pm 0.17$ & $1.11 \pm 0.14$ \\
PCl & nd & nd & nd \\
Cop 4.5 & $1.08 \pm 0.13$ & $\mathbf{1 . 5 4} \pm 0.07^{\star}$ & $1.47 \pm 0.18^{+}$ \\
Carotid artery & - & - & $1.05 \pm 0.13$
\end{tabular}

"Significantly different from the inner diameter of the carotid artery and the vein grafts supported by the PEU-PCI and the PEU-PLLA prostheses 3 wk after implantation $(P<0.01)$

${ }^{t}$ Significantly different from the inner diameter of the carotid artery and the vein grafts supported by the PEU-PCI and PEU-PLLA prostheses 6 wk after implantation $(P<0.01)$

Values are given as mean \pm s.d. nd, no dilation (not measured)

Table 4 Wall thickness (intima and media) of the implants

\begin{tabular}{llll}
\hline Graft & \multicolumn{3}{c}{ Wall thickness $(\mu \mathrm{m})$} \\
\cline { 2 - 4 } & $\begin{array}{l}\text { 1 wk } \\
\text { implants }\end{array}$ & $\begin{array}{l}3 \text { wk } \\
\text { implants }\end{array}$ & $\begin{array}{l}6 \mathrm{wk} \\
\text { implants }\end{array}$ \\
\hline PEU-PCI & $63 \pm 21$ & $121 \pm 25$ & $125 \pm 32^{*}$ \\
PEU-PLLA & $67 \pm 20$ & $138 \pm 56$ & $194 \pm 29$ \\
PCI & $\mathrm{nm}$ & $\mathrm{nm}$ & $\mathrm{nm}$ \\
Cop 4.5 & $67 \pm 13$ & $142 \pm 38$ & $163 \pm 30^{\dagger}$ \\
Carotid artery & - & - & $206 \pm 22$
\end{tabular}

*Significantly different from the wall thickness of the carotid artery and the vein gratts supported by the PEU-PLLA prostheses $6 \mathrm{wk}$ after implantation $(P<0.01)$.

'Significantly different from the wall thickness of the carotid artery $(P<0.05)$. Values are given as mean \pm s.d. $\mathrm{nm}$, not measured.

grafts the inner diameter was equal to that of the adjacent artery (see Table 3). In all cases the wall of the vein grafts was increased in thickness as compared to the 1 wk implants but was still thinner than that of the adjacent artery (see Table 4). The wall thickness was increased by the development of regular layers of circularly oriented cells, most likely young and immature fibroblasts, beneath the well preserved smooth muscle cell layers ${ }^{29}$. The Cop 4.5 prostheses were degraded excessively; only fragments of the prosthetic material were left. The PEU-PLLA prostheses were also fragmented, although less excessively than the Cop 4.5 prostheses. The PEU-PCl and PCl prostheses did not show signs of fragmentation. The Cop 4.5 prostheses showed infiltration of many capillaries and multinuclear giant cells over the whole thickness of the prosthetic wall. The same picture was seen in both PEU-based prostheses, whereas only very limited perigraft tissue ingrowth was observed in the PCl prostheses.

Six week implants: the vein grafts supported by the Cop 4.5 prostheses did not show a further dilation. In all other cases the inner diameter of the vein grafts still equalled that of the adjacent artery (see Table 3). The wall of the dilated vein grafts supported by the Cop 4.5 prostheses was further thickened as compared to the $3 \mathrm{wk}$ implants but was still thinner than that of the adjacent artery. The wall thickness of the vein grafts supported by the PEU-PLLA prostheses had reached that of the adjacent artery, whereas those of the vein grafts supported by the PEU-PCl prostheses (see Figure $4 d$ ) were still thinner than that of the adjacent artery (see Table 4). No remnants of the Cop 4.5 prostheses could now be observed. The PEU-PLLA prostheses had fallen apart into fragments. The PEU$\mathrm{PCl}$ prostheses were also fragmented, although less excessively than the PEU-PLLA prostheses. The PCl prostheses still seemed unaffected. The Cop 4.5, PEUPLLA and PEU-PCl prostheses showed the infiltration of many capillaries and multinuclear giant cclls over the whole thickness of the prosthetic wall. The PCl prostheses showed only limited perigraft tissue ingrowth.

Wrinkling or folding of the vein grafts was never observed during the $6 \mathrm{wk}$ of implantation.

\section{DISCUSSION}

Our results clearly demonstrate that the arterialization of autologous vein grafts used for the reconstruction of small diameter arteries is improved when a microporous, elastomeric and degradable prosthesis supports the vein graft. The results particularly demonstrate that the vein grafts adapt gradually and regularly to the arterial conditions when the degradation of the prostheses is in step with the biological regeneration process.

After implantation, the control grafts showed severe destructive changes including de-endothelialization, complete disruption of the smooth muscle layers with edema, disintegration of the elastic laminae and an inflammatory reaction.

In contrast, the prostheses used to support the vein grafts reduced these destructive changes and prevented an inflammatory reaction in the wall. The severe destructive changes observed in the control vein grafts can therefore only be ascribed to the distension by the arterial pressures and pulsatile blood flow. We used oversized vein grafts in the prostheses to ensure that overstretching could not occur. Therefore, the minor damage still observed might be ascribed to the handling procedures during transplantation and ischaemia. In time, the wall of the vein grafts gradually increased in thickness by the formation of regular circularly oriented cellular layers beneath the original longitudinally oriented smooth muscle cell layers, indicating a regular adaptation of the vein wall to the arterial blood pressures and pulsatile blood flow, i.e. arterialization. These circularly oriented cellular layers consisted of young and immature fibroblasts ${ }^{29}$, which have the potential to transform into smooth muscle cells. Because the fibroblast layers formed highly organized structures, this transformation is likely to occur or had already been started. However, long-term in vivo experiments are required to investigate whether under these conditions the fibroblasts are indeed transformed into smooth muscle cells and a medium resembling that of an artery of normal architecture and function develops. In contrast, the control vein grafts showed no regularly and circularly oriented cellular layers at $6 \mathrm{wk}$ and because of the mature aspect of fibroblasts, a transformation of the fibroblasts into smooth muscle cells is not likely.

According to 7.wolak ef $a l^{31}$, vein grafts adapt to the arterial conditions by a thickening of their wall. This thickening proceeds until the ratio of the inner 
diameter and the wall thickness has reached the same value as that of the adjacent artery. Cell stretching induces cell proliferation and stimulates cells to produce and to release extracellular matrix components ${ }^{32-35}$. Adaptation of the vein graft to the arterial conditions by thickening of the wall can be ascribed to these biological processes. However, when unsupported vein grafts are used, thickening of the vein wall is accompanied by an increase of the inner diameter ${ }^{31}$. Dilation of the unsupported vein grafts beyond the diameter of the artery can be prevented by using smaller diameter veins. However, damage in the vein wall due to overstretching remains.

The arterialization process of the vein grafts supported by the prostheses can be explained by the following mechanism. Immediately after implantation, graft dilation is prevented by the presence of a supporting prosthesis around the vein graft. In time, the prosthesis degrades and its supporting function is gradually lost. This gradual loss of the support combined with the elastomeric properties of the prostheses results in a slow increased stretching of the vein graft wall without damage caused by acute overstretching. As a consequence, cell proliferation and the production and release of extracellular matrix components are slowly induced, resulting in a thickening of the vein graft wall, by which the increased stretching is counteracted. Because the loss of support is a gradual process, adaptation of the vein graft to the arterial conditions proceeds in a gradual way. Since disruption of cellular layers and the inflammatory reaction are prevented, the structure of the vein wall regenerates normally and shows no degeneration into fibrosis like the acutely overstretched unsupported vein grafts. The process of vein wall thickening proceeds until the ratio of the inner diameter and the wall thickness has reached the same value as that of the adjacent artery. By that time the vein graft has acquired sufficient strength to withstand the arterial blood pressures and the pulsatile blood flow. When the supporting prosthesis degrades very rapidly, the loss of support may be too rapid. In this case, thickening of the vein graft wall cannot keep pace with the loss of support of the prosthesis. This process was observed with the vein grafts supported by the Cop 4.5 prostheses. Already, within $3 \mathrm{wk}$ of implantation, the Cop 4.5 prostheses had degraded excessively. At this time the vein grafl was dilated as compared to the adjacent artery. Although the wall thickness had increased after 6 wk of implantation, the ratio of the inner diameter and the wall thickness of the vein graft had not vet reached the same value as that of the adjacent artery. Therefore, it is expected that in time the wall thickness will increase in size. The PEUPLLA prostheses were fragmented excessively after 6 wk of implantation and had most likely lost their supporting function completely ${ }^{26}$. At that time the vein wall had already reached the same thickness as that of the adjacent artery and graft dilation was not observed. Therefore, we may conclude that the rate of degradation of the PEU-PLLA prostheses induced an optimal arterialization of the vein graft and that the arterialization process was more or less completed within 6 wk. The PEU-PCl prostheses were fragmented less excessively than the PEU-PLLA prostheses after $6 \mathrm{wk}$ of implantation and most likely still supported the vein grafts to some extent ${ }^{26}$. The vein grafts supported by the PEL-PCl prostheses were not dilated but had also not reached the wall thickness of that of the adjacent artery. It is likely that after prolonged implantation times, during which the supporting function of the prosthesis decreases further, vein graft wall thickening without graft dilation will proceed until the arterialization process is completed. After 6 wk of implantation the PCl prostheses did not show any macroscopical signs of degradation and most likely retained their initial mechanical strength. It is therefore likely that at this time the arterialization process had not yet finished.

From these results it can be concluded that the degradation rate of the prostheses determines the arterialization rate of the vein grafts. However, since thickening of the vein graft wall is limited to a certain maximum rate, the degradation of the prostheses should also not exceed that rate to prevent graft dilation.

Preferably, a foreign material should remain in the body only as long as it is required. In our animal model, the PEU-PLLA prostheses induced the best balance of rapid degradation and optimal arterialization of the vein grafts. However, the degradation rate in a clinical situation might be different since the arterialization rate is likely to be species dependent ${ }^{36,37}$ and is furthermore determined by the original thickness of the vein graft wall. Therefore, a series of prostheses differing in degradation rate should be available.

In the present study we used two different PEU-based prostheses, the PEU-PLLA and PEU-PCI prostheses, which lost their supporting function at different rates. In a previous study, in which these prostheses were used as vascular substitutes, it was shown that the prostheses fragment in vivo by alternating stresses induced by arterial pulsations ${ }^{26}$. By changing the composition of these prostheses, a series of prostheses with a broad range of fragmentation rates can be obtained $^{26,38}$. Therefore, this series of prostheses seems ideal as supporting prostheses for vein grafts. However, care must be exercised to apply fragmentable prostheses based on polyurethanes in humans because it is not known how long it takes until the polymer fragments are degraded completely and wheher degradation products accumulate in the body. Moreover, when polyurethanes in which the hard segments are based on aromatic diisocyanates are used, highly toxic aromatic diamines may be formed during degradation ${ }^{39-44}$.

Alternatives for blend prostheses are prostheses composed of biodegradable elastomeric copolymers which are built up from non-toxic naturally occurring metabolites and of which the degradation rate can be varied by changing the monomer ratio. The Cop 4.5 and PCl prostheses used in the present sludy belong to such a series of prostheses. It was found that the PCl prostheses degraded slowly. Qualitative inspections of the implant $6 \mathrm{wk}$ after implantation did not show any loss of integrity of the prostheses and even 6 months after implantation the prostheses still seemed 
relatively unaffected (data not shown). In contrast, the Cop 4.5 prostheses degraded very rapidly. After $3 \mathrm{wk}$ of implantation only fragments of the material were left and after $6 \mathrm{wk}$ of implantation the material had completely disappeared. These findings indicate that a series of prostheses with a very broad range of degradation rates can be prepared by varying the $\varepsilon$-caprolactone-morpholinedione ratio between 95.5:4.5 and 100:0. Therefore, we recommend prostheses made of these copolymers to support the vein grafts.

\section{ACKNOWLEDGEMENTS}

This study was financially supported by the Dutch Technology Foundation (STW).

\section{REFERENCES}

1 Fhrenfeld WK, Stoney RJ, Wylie EJ. Autngenous arterial grafts. In: Stanley JC, Burkel WE, Lindenauer SM, Bartlett RH, Turcotte JG, eds. Biologic and Synthetic Vascular Prostheses. New York: Grune \& Stratton, 1982: 291-309.

2 Sottiurai VS, Batson RC. Autogenous vein grafts: experimental studies. In: Stanley JC, Burkel WE, Lindenauer SM, Bartlett RH, Turcotte JG, eds. Biologic and Synthetic Vascular Prostheses. New York: Grune \& Stratton, 1982: 311-331

3 Stanley JC, Graham LM, Whitehouse WM, Lindenauer SM, Zelenock GB, Cronenwett JL. Autogenous vein as an arterial graft: clinical status. In: Stanley JC, Burkel WE, Lindenauer SM, Bartlett RH, Turcotte JG, eds. Biologic and Synthetic Vascular Prostheses. New York: Grune \& Stratton, 1982: 333-349.

4 Lytle BW, Loop FD, Cosgrove DM, Ratliff NB, Easley K, Taylor PC. T.ong-term ( 5 to 12 years) serial studies of internal mammary artery and saphenous vein coronary bypass grafts. J Thorac Cardiovasc Surg 1985; 89: 248258.

5 Dilley RJ, McGeachie JK, Prendergast FJ. A review of histologic changes in vein to artery grafts, with particular reference to intimal hyperplasia. Arch Surg 1988; 123: 691-696.

6 Senatore F, Shankar H. Development of biocompatible vascular prostheses. Crit Rev Biocompat 1988; 4: 281.

7 Baird RN, Abbott WM. Vein grafts: an historical perspective. Am J Surg 1977; 134: 293-296.

8 Rich NM, Clagett GP, Salander JM. Aneurysmal dilatation in venous grafts used in reconstructions of injured arteries. In: Wright CD, ed. Vascular Grafting: Clinical Applications and Techniques. Boston: PSG, 1983: 229235.

9 Callow AD. Historical overview of experimental and clinical development of vascular grafts. In: Stanley JC, Burkel WE, Lindenauer SM, Bartlett RH, Turcotte JG, eds. Biologic and Synthetic Vascular Prostheses. New York: Grune \& Stratton, 1982: 11-26.

10 Adconk OT, Adrnck GID, Wheeler JR, Gregory RT, Snyder SO, Gayle RG. Optimal techniques for harvesting and preparation of reversed autogenous vein grafts for use as arterial substitutes: a review. Surgery 1984; 96: $886-894$.

11 Boerboom LE, Bonchek LI, Kissebah AH, Werner PH, Pepper JR, Olinger GN, Korns ME, Garancis JD. Effect of surgical trauma on tissue lipids in primate vein grafts. Relation to plasma lipids. Circulation 1980; 62, Suppl. 1: 142-147.

12 Ramos JR, Berger K, Mansfield PB, Sauvage LR. Histologic fate and endothelial changes of distended and nondistended vein grafts. Ann Surg 1976; 183: 205-228.

13 Fonkulsrad EW, Sanchez M, Zerubavel R. Morphological evaluation of canine autogenous vein grafts in the arterial circulation. Surgery 1978; 84: 253-264.

14 Baumann FG, Catinella FP, Cunningham JN, Spencer FC. Vein contraction and smooth muscle cell extensions as causes of endothelial damage during graft preparation. Ann Surg 1981; 194: 199-211.

15 Olinger GN, Boerboom LE, Bonchek LI, Hutchinson LD, Kissebah AH. Hyperkalemia in cardioplegic solutions causing increasing cholesterol accumulation in vein grafts. I Thorac Cardiovasc Surg 1983; 85: 590-594.

16 Maloney JM, Kischer CW, Moore WC. Changes in venous endothelial fibrinolytic activity and histology with in vitro venous distention and arterial implantation. Am J Surg 1981; 142: 178-183.

17 King P, Royle JP. Autogenous vein grafting in atheromatous rabbits. Cardiovasc Res 1971; 6: 627-633.

18 Smitten KV, Stenman S, Jiborn H, Ahonen J, Scheinin TM. Connertive tissue changes and collagen metabolism in syngenic vena caval grafts in rats. Acta Chr Scand 1983; 149: 27-32.

19 Boerboom LE, Olingen GN, Bonchek LI, Gunay II, Kissebah AH, Rodriques ER, Ferrans VJ. The relative influence of arterial pressure versus intraoperative distension on lipid accumulation in primate vein bypass grafts. I Thorac Cardiovasc Surg 1985; 90: 756764.

20 Bond MG, Hostetler JR, Karayannacos PE, Geer JC, Vasko IS. Intimal changes in arteriovenous bypass grafts. Effects of varying the angle of implantation at the proximal anastomosis and of producing stenosis in the distal runoff artery. I Thorac Cardiovasc Surg 1976; 71: 907-916.

21 Barra JA, Volant A, Leroy JP, Braesco J, Airiau J, Boschot J, Blanc JJ, Penter P. Constrictive perivenous mesh prosthesis for preservation of vein integrity: experimental results and application for coronary bypass grafting. I Thorac Cardiovasc Surg 1986; 92: 330-336.

22 Karayannacos PE, Hostetler JR, Bond MG, Kakos GS, Williams RA, Kilman JW, Vasko JS. Late failure in voin grafts; mediating factors in subendothelial fibromuscular hyperplasia. Ann Surg 1978; 187: 183-188.

23 Wesley RLR, Vainshnav RN, Fuchs JCA, Patel DJ, Greenfield JC. Static linear and nonlinear elastic properties of normal and arterialized venous tissue in dog and man. Cir Res 1975; 37: 509-520.

24 White RA, Hirose FM, Sproat RW, Lawrence RS, Nelson RJ. Histopathologic observations after short-term implantation of two porous elastomers in dogs. Biomaterials 1981; 2: 171-176.

25 in't Veld PJA, Ye W-P, Klap R, Dijkstra PJ, Feijen J. Copolymerization of $\varepsilon$-caprolactone and morpholine2,5-dione derivatives. Makromol Chem 1992; 193: 1927-1942.

26 Hinrichs WLJ, Kuit J, Feil H, Wildevuur ChRH, Feijen J. The in vivo fragmentation of microporous polyurethane- and copnlyesterether-hased vascular prostheses. Biomaterials 1992; 13: 585-593.

27 Hinrichs WLJ. Porous polymer structures for tissue regeneration. Dissertation, University of 'Twente, Enschede, The Netherlands, 1992.

28 Bartels HL, van der Lei B. Microvascular grafting with biodegradable prostheses into the rat abdominal aorta. Laboratory Animals 1988; 22: 112. 
29 Zweep HP, Satoh S, van der Lei B, Hinrichs WLJ, Dijk F, Feijen J, Wildevuur ChRH. Autologous vein supported with a biodegradable prosthesis for arterial grafting. Ann Thorac Surg 1993; 55: 427-433.

30 Zweep H-P, Satoh S, van der Lei B, Hinrichs WLJ, Feijen J, Wildevuur ChRH. Biodegradation of supported, compliant prosthesis can optimize the process of arterialization of autologous vein grafts in rabbits. Ann Thorac Surg (accepted for publication).

31 Zwolak RM, Adans MC, Clowes AW. Kinetics of vein graft hyperplasia: association with tangential stress. I Vasc Surg 1987; 5: 126-136.

32 Yue X, van der Lei B, Schakenraad JM, van Oene GH, Kuit JH. Feijen J, Wildevuur ChRH. Smooth muscle cell seeding in biodegradable grafts in rats: a new method to enhance the process of arterial wall regeneration. Surgery 1988; 103: 206-212.

33 van der Lei B, Wildevuur ChRH, Dijk F. Blaauw EH, Molenaar I. Nieuwenhuis P. Sequential studies of arterial wall regeneration in microporous, compliant, biodegradable small-calibre vascular grafts in rats. $J$ Thorac Cardiovasc Surg 1987; 93: 695-707.

34 van der Lei B. Nieuwenhuis P, Molenaar I, Wildevuur ChRH. Long-term biologic fate of neoarteries regenerated in microporous, compliant, biodegradable smallcalibre vascular grafts in rats. Surgery 1987; 101: 459467.

35 Leung PYM, Glagov S, Mathews MB. Cyclic stretching stimulates synthesis of matrix compounds by arterial smooth muscle cells in vitro. Science 1976; 191: 475477 .
36 Senatore F, Shankar H, Venkataramani ES. Development of biocompatible vascular prostheses. CRC Crit Rev Biocompat 1988; 4: 281-340.

37 van der Lei B, Robinson PH. Bartels HL, Wildevuur ChRII, Microarterial grafting into carotid artery of the rabbit: some considerations concerning speciesdependent thrombogenicity. Br I Plast Surg 1989; 42: $59-64$

38 van der Lei B, Bartels HL, Nieuwenhuis P. Wildevuur ChRH. Microporous, compliant. biodegradable vascular grafts for the regeneration of the arterial wall in rat abdominal aorta. Surgery 1985; 98: 955-963

39 Kopecek J, Ulbrich K. Biodegradation of biomedical polymers. Prog Polym Sci 1983; 9: 1-58.

40 Batich C, Williams J, King R. Toxic hydrolysis product from a biodegradable implant. / Biomed Mater Res 1989; 23: 311-319.

41 Paynter RW, Askill IN, Glick SH, Guidon R. The hydrolytic stability of Mitrathane (a polyurethane urea) - an X-ray photoelectron spectroscopic; study. I Biomed Mater Res 1988; 22: 687-698

42 Marchant RE, Zhao Q, Antersun JM, Hilner A. Degradation of poly(ether urethane urea) elastomer; infra-red and XPS studies. Polvmer 1987: 28: 20322039.

43 Phua SK, Castillo E, Anderson JM. Hiltner A. Biodegradation of polyurethane in vitro. I Biomed Mater Kes 1987; 21: 231-246.

44 Smith R, Williams DK, Oliver C. The biodegradation of poly(ether urethanes). J Biomed Mater Res 1987; 21: $1149-1166$

\section{Bioceramics Volume 6}

\section{Edited by $\mathbf{P}$ Ducheyne and D Christiansen}

Bioceramics 6 is the proceedings of the 6th International Symposium on Ceramics in Medicine, held in Philadelphia, USA in November 1993.

Some 78 contributions from internationally-recognised experts address the key areas of current research in ceramic materials for orthopaedic, cardiovascular, dental and other applications.

This extensive account of present understanding in bioceramics will be vital reading for academic and industrial researchers, and lecturers and students in material science, medical engineering and clinical implantology.

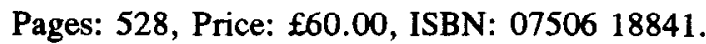

Please send me copies of Bioceramics $6 @ £ 60.00+£ 2.00$ postage. I enclose payment of $£$

Sterling cheque (drawn on a UK bank)/Eurocheque/Money Order/Postal Order enclosed

(Made payable to Reed Book Services Ltd)

Please invoice my company (please attach this form to an official purchase order)

Access/Eurocard/Mastercard $\square$ American Express $\square$ Visa $\square$ Diners Club If paying by credit card, please use the address shown on your credit card statement.

Expiry date

Name (please print)

Address

Country Postcode/Zip

To order this book, please contact: Reed Book Services Ltd., P.O. Box 5, Rushden, Northants NN10 9YK. Tel: (0933) 58521. Fax: (0933) 50284. Telex: 312504. 